\title{
Т. Уяма
}

Центр славянско-евразийских исследований Университета Хоккайдо (Саппоро, Япония)

\section{Идея и реальность казахского автономизма в годы Гражданской войны в России: самостоятельность и зависимость народов в квази-имперском пространстве}

После Октябрьской революции лидеры казахского национального движения образовали автономное правительство Алаш-Орда. Они изъявили решимость самостоятельно управлять автономным государством, обсуждали вопросы о национализме и стремились поднять национальный дух казахов. Но осуществление идеи автономии на практике оказалось непростым в силу сложной военно-политической ситуации Гражданской войны в России. Чтобы достичь максимально возможной самостоятельности, они должны были вести диалог и взаимодействовать с различными политическими силами России, частично принимая их видение российского государства. Это привело к расхождению идеи автономизма и реального политического положения казахов, а также к частым и резким изменениям их позиции между красными и белыми. Их поиск пути к автономии был ярким примером проявления энергии прежде угнетенных народов, но в то же время свидетельствовал об их зависимости от ситуации в пространстве, где имперская власть исчезла, но сильно действовало стремление к восстановлению великой державы.

Ключевые слова: Алаш-Орда, казахские интеллигенты, автономия, национализм, Гражданская война в России, квази-имперское пространство.

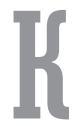

ак известно, война и национализм ${ }^{1}$ имеют тесную взаимосвязь. Национализм может стать одной из причин войны, которая, в свою очередь, стимулирует рост национализма в воюющих странах. Крупная война также может разрушить многонациональное государство и породить новые национальные государства. Но если война не межгосударственная, а гражданская,

${ }^{1}$ Следуя практике западной историографии, я употребляю слово «национализм» в нейтральном смысле, не вкладывая в него негативное или позитивное значение. Следует также отметить, что казахские авторы в рассматриваемый нами период часто употребляли слово «ұлтшылдық», которое переводится как национализм, в смысле «любви к нации». 
причем не межнациональная, какую связь могут иметь война и национализм?

Гражданская война в России в основном была войной между большевиками и антибольшевистскими силами, но в нее вовлекались различные группы, которые представляли нерусские народы. Национальный вопрос в годы Гражданской войны, то есть политика большевиков и белого движения по отношению к нерусским народам, а также отношение национальных движений к красным и белым достаточно хорошо изучены ${ }^{2}$. Но в исследованиях этого вопроса национализм (или, говоря шире, идеи о нации) представляется заданным фактором и не рассматриваются его развитие или изменения во время Гражданской войны. Нет сомнения, что национализм развивался в последние годы существования Российской империи и в революционном 1917 г., но возможное влияние конфликтов после Октябрьской революции и во время Гражданской войны на национализм народов бывшей Российской империи тоже заслуживает внимания. Именно в этот период многие национальные движения впервые получили возможность более или менее самостоятельно управлять политической жизнью своих народов, в то же время сталкиваясь со многими трудностями.

В данной статье мы рассматриваем развитие идей о нации и автономии и трудности их применения после Октябрьской революции и до окончания Гражданской войны на примере казахов. Кроме русскоязычных источников, для изучения идей лидеров казахского национального движения используются казахоязычные источники, в том числе газета «Сары-Арка» (1917-1919 гг.) и журнал «Абай» (1918 г.).

\section{Эволюция идеи автономизма}

Казахские интеллигенты, руководившие политическим движением, до распада Российской империи в основном требовали введения земств и возвращения избирательных прав в Государственную думу, ставя своей целью участие в политической жизни России. Даже после Февральской революции они не сразу наметили путь к автономии. Резолюции казахского съезда Семипалатинской области, состоявшегося 27 апреля - 7 мая 1917 г., стали первым коллективным

2 См., например: Аманжолова Д. А. Казахский автономизм и Россия: история движения Алаш. М., 1994. 213 с.; Исхаков С. М. Российские мусульмане и революция: весна 1917 г. - лето 1918 г.: 2-е изд. М., 2004. 598 с.; Нам И.В. Национальные меньшинства Сибири и Дальнего Востока на историческом переломе (1917-1922 гг.). Томск, 2009. 496 c. 
выражением воли казахских политических деятелей добиться автономии. Составители проекта программы партии Алаш, опубликованного 21 ноября 1917 г., то есть уже после Октябрьской революции, выступили за то, чтобы Россия стала федеративной республикой, состоящей из равноправных государств. Но проект не очень четко определил полномочия автономии как федеративной единицы и допускал возможность объединения казахской автономии с соседними народами. Еще в середине октября 1917 г. на Сибирском областном съезде в Томске казахские делегаты заявляли, что казахи временно присоединятся к сибирской автономии. Таким образом, руководители казахского национального движения осторожно и медленно развивали идею автономии ${ }^{3}$.

В сложной обстановке после Октябрьской революции они начали действовать на опережение. 2-й Всеказахско-кыргызский съезд, который состоялся 5-13 декабря 1917 г. в Оренбурге, постановил образовать территориально-национальную автономию всех населенных казахами и кыргызами территорий областей Степного и Туркестанского краев, Букеевской орды и Алтая. Съезд также решил организовать Временный народный совет Алаш-Орда, который впоследствии называл себя и правительством. При этом большинство участников съезда выступили против немедленного объявления автономии, полагая, что сначала нужно организовать милицию (вооруженные отряды) для самозащиты и провести переговоры с казахами Туркестанского края и с другими народностями в казахских областях. Съезд обязал Алаш-Орду в месячный срок со дня своего сформирования выяснить возможность присоединения всех казахов Туркестана к автономии Алаш и потом объявить автономию ${ }^{4}$. Таким образом, съезд выразил стремление к созданию единой автономии, которая объединила бы казахов и кыргызов, разобщенных административным делением бывшей Российской империи.

В январе 1918 г. газета «Сары-Арка» опубликовала несколько статей, разъяснивших суть и необходимость автономии. Автор «Алимхан» ${ }^{5}$ приветствовал автономию Алаш словами «народ без отечества обрел отечество (отансыз жұрт отанды болды)». Имея в виду

3 Уяма Т. Эволюция идеи автономии Алаш на волне общероссийских политических событий до и во время революции // Сборник статей международной научной конференции «От Алаш к независимости и национальной консолидации Казахстана», посвященной 100-летию движения Алаш и Правительства АлашОрды. Орал, 2017. С. 315-325.

4 Алаш қозғалысы - Движение Алаш. Сборник документов и материалов. Т. 1. Алматы, 2004. С. $472-482$.

5 Скорее всего, это был член Алаш-Орды Алимхан Ермеков (1891-1970), также избранный членом временного Сибирского областного совета. 
серьезность земельного вопроса у казахов и кыргызов, вызванного переселением русских крестьян, он считал, что «автономия - большое оружие для защиты нашей земли от людей, желающих взять долю». По его мнению, в автономии народ должен управлять властью, издав законы, соответствующие обычаям о земле, воде, быте и хозяйстве 6 .

По поводу формы государственного устройства «Габбас» ${ }^{7}$ разъяснил, что «автономный народ берет свои поводья в свои руки и вверяет только кончик чембура центральному правительству. <..> Мы не отделимся полностью от российского государства», проводя аналогию со Швейцарией и США, где в каждом кантоне или штате есть министры, парламенты и суды, но в отношении других стран или внешних врагов союз кантонов или штатов действует как одна страна. Он также аргументировал, что автономия нужна для того, чтобы поднимать культуру, сохранять нацию, быть хозяином самого себя и родных краев, занимать место среди народов и достигать целей нации ${ }^{8}$.

Из этих статей видно, что автономия, согласно идее деятелей движения Алаш, резко отличалась от советской автономии, которую казахи получили позже. Они не предусматривали вмешательство центрального правительства во внутренние вопросы и понимали автономию как самостоятельное управление, защищающее земли от захвата переселенцами.

Тогда как многие из них открыто не выражали вражду к России и русским, автор с псевдонимом «Жас Алаш» придерживался иной позиции. Он написал, что ранее казахские делегаты были вынуждены выступить за присоединение к сибирской автономии, потому что великороссы не открывали казахам путь к собственной автономии, а также потому что сами казахи думали, что их культурный уровень недостаточен для управления ей. Но если тогда Российское государство еще не разошлось по швам, то теперь политическая ситуация изменилась. Народы, которые ранее и не думали отделиться от России, теперь снимали кандалы великороссов. Но большевики терзали непослушный народ. Чтобы не примиряться с рабством, по мнению автора, правильно было бы поставить белую орду (то есть установить свою власть), подняв знамя Алаша, пока великороссы

6 Әлімхан. Жасасын алаш, жасасын! (1918. 22 января) // Алаш көсемсөзі. 10-кітап: Сарыарқа. Алматы, 2011. С. 74-78.

7 Возможно, это был Халел Габбасов (1888-1931), член Алаш-Орды и один из редакторов газеты «Сары-Арка».

8 Ғаббас. Алаш автономиясы (1918. 22 января) // Алаш көсемсөзі. 10-кітап: Сарыарқа. Алматы, 2011. С. 79-83. 
дрались с другом и обессиливали. «Великороссы легко не дадут автономию, когда придут в себя. <..> Если мы не сможем терпеть издержки и труд для автономии, мы тоже будем уничтожены пожаром, который истребляет великороссов», - написал Жас Алаш ${ }^{9}$. Позже он написал статью «Господство великороссов», в которой подчеркнул, что «независимо от того, какая партия русских придет к власти, не будет равенства и свободы в отношении к нам, <...> и богатые и бедные из русских хищничают казахов», приравнивая власть рабочих и солдат к хозяйничанью великорусской бедноты ${ }^{10}$.

\section{Обсуждение вопросов о национализме}

Несмотря на большую надежду казахов на автономию, из-за установления Советской власти в казахских областях Алаш-Орда не смогла ни приступить к полноценной работе, ни официально объявить автономию. В феврале - марте 1918 г. несколько авторов статей газеты «Сары-Арка» выразили недовольство тем, что большевики не дают народам осуществить права на самоопределение, которые они сами неоднократно декларировали ${ }^{11}$. В частности, МирЯкуб Дулатов (1885-1935) ${ }^{12}$ с озабоченностью отметил, что большевики уничтожают автономии Украины, Сибири, Туркестана, башкир и Крыма, называя их буржуазными автономиями. Он считал, что, хотя неизвестно, постигнет ли такая же участь алашскую автономию в случае ее официального объявления, угрозу представляли казахские большевики-доносчики, в том числе и бывший миссионер, и бывший агент жандармерии, которые призывали к уничтожению членов Алаш-Орды ${ }^{13}$. На его взгляд, осуществлению национальной автономии мешали не только внешние силы, но и враги внутри нации.

Примечательно, что именно в такой обстановке с неопределенной перспективой казахские интеллигенты начали философски обсуж-

\footnotetext{
9 Жас Алаш. Күш - бірлікте (1918. 12 января) // Там же. С. 56-59.

10 Жас Алаш. Ұлы орыстың үстемдігі (1918. 12 февраля) // Там же. С. 114-117.

11 См., например, анонимную статью: Мемлекет күйі (1918. 22 марта) // Там же. С. $198-200$.

12 Дулатов известен как автор сборника стихов «Оян, қазақ! (Проснись, казах!)», изданного в 1910 г. Он не был членом Алаш-Орды, но фактически был одним из видных руководителей движения Алаш.

13 Мадияр (Дулатов. М.). Кім дос, кім қас? (1918. 3 марта) // Алаш көсемсөзі. 10-кітап: Сарыарқа. Алматы, 2011. С. 139-141. Вероятно, под бывшим миссионером и бывшим агентом жандармерии подразумевались, соответственно, известные большевики Алиби Джангильдин (1884-1953) и Мухамедьяр Тунгашин (1888-1942), которых Дулатов неоднократно подвергал жесткой критике.
} 
дать вопросы о национализме. В журнале «Абай» в феврале 1918 г. учитель и журналист Маннан Турганбай (1886-1937) привел аргументы человеколюбцев, которые переживали за все человечество и осуждали националистов ${ }^{14}$ за раздувание вражды между нациями, и аргументы националистов, которые переживали за свою нацию и считали, что человеколюбие не появляется из народа, не знающего чувство национального достоинства, а развивается тогда, когда все нации становятся на один уровень культуры. Сам Турганбай согласился с националистами, считая, что человек сначала любит себя, потом своих родных, потом свой народ и только потом может любить все человечество и что национализм не противостоит человеколюбию. По его мнению, пока что казахам следовало развивать национализм для того, чтобы принести культуру и счастье ${ }^{15}$.

А известный поэт и мыслитель Шакарим Кудайбердиев (18581931) поставил под сомнение суждение Турганбая, задав вопрос: «Европейцы, у которых национализм и культура находятся в высшей степени, осуществляют человеколюбие?». Шакарим утверждал, что национализм рождает культуру, но не может рождать чистое сердце, которое восполняет недостаток национализма. Без умножения чистых сердец или «ұждан» - слово, которое переводится как «совесть», но в которое Шакарим вкладывал такие значения как любовь к человеку, милость и справедливость - нельзя достичь человеколюбия ${ }^{16}$. Таким образом, хотя Шакарим не отказался от национализма, он считал, что национализм должен восполняться совестью, ведущей к человеколюбию.

Казахские интеллигенты и позже продолжали обсуждать вопросы о национализме в журнале «Абай». Характерно, что они часто извлекали уроки из опыта России и русских. Молодой деятель движения Алаш и будущий крупный советский казахский писатель Мухтар Ауэзов (1897-1961) отметил в статье «Культура и нация», что к человеколюбию стремятся социализм и эсперанто, но они распространяются именно в европейских странах, в том числе и в России, которые воюют друг с другом, и кровавая война затягивает осуществление социализма. Увязшая в сугробе Россия дает хороший урок следующим за ней народам, и теперь каждая нация убеждается,

\footnotetext{
14 Говоря об этих категориях людей, Турганбай использовал парные слова «кісішіл» и «ұлтшыл». Но так как в русском языке нет таких слов как «человекист» или «нациелюбец», я вынужден использовать слова, которые не являются парой: человеколюбец и националист.

15 Мәннән Тұрғанбай. Ұлтшылдық (1918. 28 февраля) // Алаш көсемсөзі. 8-кітап: Абай. Алматы, 2011. С. 88-91.

16 Шәкәрім. Ұлтшылдық туралы (1918. 20 марта) // Там же. С. 131.
} 
что нужно сделать свою культуру национальной, хотя участвовать в благородной культуре вместе с народами мира тоже будет честью для казахской нации ${ }^{17}$. Через слова Шакарима и Ауэзова можно понять, насколько сильно повредила кровавая Первая мировая война имидж Европы, которая раньше являлась символом прогресса в глазах казахских интеллигентов ${ }^{18}$.

Статья Ауэзова была двусмысленна в отношении к национализму, а анонимный автор статьи «Любить нацию», предположительно, редактор журнала Жусипбек Аймауытов (1889-1931), был более прямолинеен. Он отметил, что эгоизм усиливается по мере развития культуры и пока еще далеко до того времени, когда исчезнут насилие, вероломство и кровожадность. Нынешняя цель - не быть униженными и не исчезнуть из мира. Сильна та нация, в которой много людей, по-настоящему любящих нацию и работающих, не жалея свои силы. По мнению автора, русские, разделившиеся на разные классы и партии, не являются народом, любящим свою нацию, и у них нет ничего, что можно было бы брать в этом отношении в качестве образца для подражания. Тогда как у русских простой народ и образованные люди не любят друг друга, казахские образованные люди пользуются уважением народа и они должны учить народ любить свою нацию. В заключение автор так сформулировал свое кредо: «Не народ для нас, а мы для народа родились» ${ }^{19}$. Несмотря на его отрицательное суждение о русских, его утверждение было похоже на идею русского народничества.

Видение национализма у разных казахских интеллигентов не совпадало, но они были едины в том, что необходимо развивать любовь казахов к своей нации и поднимать их дух в борьбе за автономию. В начале 1918 г. в Семипалатинске были сформированы казахские милицейские отряды. Сначала они ни против кого не воевали открыто, но 6 марта 1918 г. вдруг появились красноармейцы, выстрелом одного из которых был убит молодой начальник милиции Казы Нурмухамедулы. На его похоронах ряд видных деятелей движения Алаш восхваляли убитого. В частности Шакарим назвал его «первым гражданином Алаша, пожертвовавшим своей душой для нации», который «показал свой нацио-

17 Мұхтар (Әуезов М.). Мәдениет һәм ұлт (1918. 25 августа) // Там же. С. 313-319.

18 О взглядах казахских интеллигентов на Европу, Россию, Японию и Монголию до 1917 г. см.: Уяма Т. Восприятие международной обстановки начала ХХ в. А. Букейханом и его современниками // «Алаш мұраты және тәуелсіз Қазақстан»: Халықаралық ғылыми-практикалық конференцияның материалдарының жинағы. Астана, 2011. С. 13-19.

19 Ұлтты сүю (1918. 12 октября) // Алаш көсемсөзі. 8-кітап: Абай... С. 347-352. 
нализм не словом, а делом» ${ }^{20}$. Позже, когда алашские отряды напрямую участвовали в Гражданской войне, было сочинено много военных песен, которые взывали к любви к родине и религиозному чувству. В одной песне пелось: «Мои предки - храбрые тюрки, мы - страна казахов. Ветряные горы, широкие озера, СарыАрка - наша земля», «Если умрем, станем истинными шахидами, если убьем, мы станем гази» ${ }^{21}$.

\section{Дискурс о «великой России» в переговорах с белыми}

Относительное затишье в первые месяцы 1918 г., когда Советская власть преобладала, но не контролировала полностью ситуацию в стране, дало возможность деятелям движения Алаш развивать идею об автономии и национализме, но не позволяло им осуществить ее на практике. Несмотря на то, что Алаш-Орда изначально носила антибольшевистский характер, ее представители провели переговоры с советским правительством в марте и апреле 1918 г., чтобы выйти из тупиковой ситуации ${ }^{22}$. В начальной стадии переговоров Советская власть, которая тоже находилась в трудном положении, позитивно относилась к Алаш-Орде. Народный комиссар по делам национальностей И. В. Сталин заявил, что можно принять решения 2-го Всеказахско-кыргызского съезда (то есть автономию казахов) при условии признания АлашОрдой Советской власти. Редакция журнала «Абай», сообщая об этом, ликующе написала: «Дети Алаша! Поднимите голову! Поздравляем вас со счастьем! Пусть непрерывно продолжаются праздники! Воскресни, Алаш! Рванись, Алаш! Радуйся, Алаш! Да здравствует Алаш!» 23 .

Но вскоре расхождение позиций Советской власти и Алаш-Орды стало явным. Более того, уральское казачество и другие антибольшевистские группы усилились на севере казахской степи и на соседних территориях, после чего переговоры прекратились. В ходе восстания Чехословацкого корпуса в конце мая - июне 1918 г. белогвардейцы и алашордынцы вытеснили большевиков из городов этих областей. Редакция журнала «Абай» теперь совсем отвернулась от большевиков, осуждая их за то, что они «продали имя социализма» и «сажали, вешали, расстреливали тех, кто сопротивлялся». Она

20 Байымбет (Майлин. Б.). Тұңғыш құрбан (1918. 20 марта) // Там же. С. 119-122.

21 Әскер өлеңі (1918.12 июля) // Там же. С. 264-265.

22 Аманжолова Д.А. Казахский автономизм и Россия... С. 34-40.

23 Қуаныш құтты болсын! (1918. 20 марта) // Алаш көсемсөзі. 8-кітап: Абай... C. 95-96. 
заявляла, что «пока большевистское правительство продолжало существовать, казахи не могли остаться благополучными» ${ }^{24}$.

Алаш-Орда начала активно работать. 24-29 июня 1918 г. она издала ряд постановлений об образовании военного совета, об организации советов Алаш-Орды в областях и уездах, о признании недействительными зачисления на переселенческие участки после Февральской революции и упразднении местных переселенческих управлений, о принятии всех государственных налогов в кассу Алаш-Орды, об учреждении казахского суда ${ }^{25}$. Но на местах часто происходила коллизия полномочий представителей Алаш-Орды и антибольшевистских правительств. Было понятно, что АлашОрда не может стабильно работать без признания со стороны последних. Сотрудничество с противниками большевиков было необходимо также потому, что казахи не несли воинскую повинность в имперский период и не имели достаточного военного опыта, поэтому отряды Алаш-Орды нуждались в помощи белых офицеров как инструкторов.

Требуя от антибольшевистских правительств признания автономии Алаш, ее деятели часто говорили, что автономии полезны объединению России, и взывали к образу России как великого государства. В сентябре 1918 г. председатель Алаш-Орды Алихан Букейханов (1866?-1937) на Государственном совещании в Уфе сказал: «Мы пойдем с русским народом, чтобы создать великую счастливую Россию». Одновременно он возражал против отождествления автономизма с сепаратизмом и на этом основании выступал против осуждения автономистов ${ }^{26}$. Более подробную аргументацию такого рода можно обнаружить в высказывании комиссара АлашОрды по Кустанайскому уезду Елдеса Омарова (1892-1937), который, сопротивляясь указу Временного Всероссийского правительства упразднить областные правительства, в ноябре 1918 г. призвал русских крестьян уезда присоединиться к автономии Алаш:

«Россия раньше, до начала настоящей мировой войны, считалась великой державой и занимала среди других государств очень важное место. <... Но после октябрьского переворота Россия, очутившись в руках советской власти, перестала быть великой державой, и положение ее среди других государств стало очень незавидное. <...> И единственным способом восстановления России в виде

${ }^{24}$ Қазіргі саяси қал (1918. 19 июня) // Там же. С. 211-213.

25 Алаш-Орда: сборник документов / сост. Н. И. Мартыненко. Кзыл-Орда, 1929. С. 91-93.

26 Государственный архив Российской Федерации (ГА РФ). Ф. 144. Оп. 1. Д. 1 а. Л. 65 об. -66. 
великой державы [Всероссийское] учредительное собрание признало привлечение к этому делу всех слоев демократии. <..> Учредительное собрание знало, что демократия еще не подготовлена к государственной работе в широком масштабе, все народы России не могут встать, как один человек, на общую работу для спасения всей России, и для привлечения их к этой великой работе необходимо, чтобы каждая область устраивалась автономно и народы этих автономных областей, каждый в отдельности, встали на работу по созданию своих автономий» 27.

А когда обращались к казакам, алашордынцы учитывали не только великодержавность России, но и свойство казаков. В сентябре 1918 г. тургайский уполномоченный Алаш-Орды Сейдазим Кадырбаев (1885?-1938) направил телеграмму войсковому кругу Оренбургского казачьего войска, в которой он приветствовал «славное казачество» и посылал «горячий привет дорогим соседям казакам». Завершалась телеграмма словами: «Да здравствует вольное казачество» ${ }^{28}$.

Многие антибольшевистские правительства не признали автономию Алаш официально, но выражение чувства принадлежности к общей родине при сохранении групповых свойств не было лишено взаимности. В августе 1919 г. войсковой круг Сибирского казачьего войска принял воззвание к казахскому народу о необходимости совместно бороться против Красной армии, подчеркивая близкие отношения и сходство между ними: «Мы, русские казаки, с вами, киргизами (казахами. - T. У.), много-много лет живем вместе добрыми соседями. <..> Мы, русские казаки, смолоду привыкли владеть конем, шашкой и ружьем; вы тоже лихие джигиты и умеете постоять за себя, шашка и пика у вас из рук не выпадут» ${ }^{29}$.

В том же месяце, после того как съезд зауральских казахов избрал А. В. Колчака «почетным аксакалом», он пожаловал им грамоту, видя в этом избрании «новое доказательство неизменного пребывания киргизского (казахского. $-T$. У.) народа в семье народностей, мирно сотрудничающих в деле возрождения родины нашей» и вознаграждая этот народ за преданность «единой и державной России» ${ }^{30}$. Это свидетельствовало о том, что в политике возглавлявшегося А.В. Колчаком Российского правительства сосуществовали идея отстаивания «единой и неделимой России» и осознание необ-

\footnotetext{
27 Алаш-Орда: сборник документов... С. 88-90.

28 Там же. С. 99-101.

29 Абдыгалиулы Б. Военные формирования Алаш-Орды (1917-1920 гг.). Астана, 2017. C. $266-267$.

30 Там же. С. 268, 271-272.
} 
ходимости учитывать бытовые особенности национальных меньшинств. Казахские деятели хорошо знали эту специфику и умели пользоваться ей, чтобы достичь, хотя бы частично, своих целей ${ }^{31}$.

Тем не менее непризнание автономии Алаш колчаковским правительством всегда оставалось серьезной проблемой в их взаимоотношениях, и по мере ослабления белого движения многие алашордынцы снова стали надеяться на осуществление автономии при Советской власти. В декабре 1919 г. Семипалатинский областной совет Алаш-Орды постановил: «Поддержать всеми средствами и силами Советскую власть, несущую свободу, равенство, братство и свет во все обездоленные темные уголки многоязычной России, приветствовать появление на территории Алаш (Киргизской автономии) советских войск, как освободителей от тирании реакционной монархической диктатуры» ${ }^{32}$.

\section{Заключение}

Накануне Октябрьской революции многие казахские интеллигенты, хотя лелеяли идеал создания автономного государства, но все же считали, что нельзя сразу осуществить его без поднятия культурного уровня казахов. Хаос после революции вынудил их думать об автономии как о насущной задаче и конкретизировать ее идею. Если в период между Февралем и Октябрем 1917 г. они верили в прогрессивные силы России, то после Октябрьского переворота появилось недоверие ко всем политическим силам России, выросло и окрепло стремление к самостоятельному управлению казахским краем, что позволило бы отражать вмешательство извне. Философское обсуждение национализма и человеколюбия тоже углублялось. Поиск пути к казахской автономии стал ярким примером проявления энергии прежде угнетенных народов после распада бывшей империи.

Хаос в России, который способствовал развитию идеи казахского автономизма и национализма, в то же время затруднял осуществление этой идеи. Обострение Гражданской войны и свержение Советской власти в казахских областях дало Алаш-Орде шанс частично осуществить самоуправление, но поставило перед ней трудную за-

31 Уяма Т. Политическая стратегия Алаш-Орды во время гражданской войны: сравнение с национально-культурной автономией тюрко-татар // Личность, общество и власть в истории России: сборник научных статей, посвященный 70-летию д-ра ист. наук, проф. В.И. Шишкина / редкол.: Т.И. Морозова (отв. секр.), В.М. Рынков (отв. ред.), А.И. Савин (отв. ред.) [и др.]. Новосибирск, 2018. С. 266-270.

32 Абдыгалиулы Б. Военные формирования... С. 283. 
дачу получить признание автономии со стороны антибольшевистских правительств. Внутри казахского общества деятели автономного движения прикладывали усилия к укреплению любви к нации и поднятию боевого национального духа, но в переговорах с противниками большевиков им приходилось подчеркивать пользу автономий для возрождения великой России.

Временное отсутствие единой власти и Гражданская война в России укрепляли стремление казахских политических деятелей к самостоятельности, но на деле они оставались зависимыми от ситуации в России. Не только белые правительства настаивали на единстве и неделимости великодержавной России, но и большевики под знаменем социализма стремились к воссоединению территории бывшей империи. В пространстве бывшей Российской империи после Октябрьской революции могли образоваться, хотя бы временно, независимые государства только на тех территориях, которые отделились от России в результате Мировой войны или в которых было сильное влияние иностранных армий (Прибалтика, Украина, Закавказье и т. д.). На остальных территориях народы, в том числе казахи, сильно зависели от соотношения сил между красными и белыми и в конце концов были включены в советское государство. Если мы понимаем империю не как государство, во главе которого стоит император, а как централизованное многонациональное государство, то подавляющую часть территории бывшей Российской империи во время Гражданской войны можно считать квазиимперским пространством, в котором мощно действовала динамика воссоздания централизованного многонационального государства. Поэтому движение любого народа за максимально самостоятельную автономию сталкивалось с большими трудностями. Эти народы не смогли избежать зависимости, однако опыт таких движений оставил глубокий след в дальнейшей истории этих народов. 